\title{
THE STABILITY OF RIGHT- AND LEFT-HANDED ALPHA-HELICES AS A FUNCTION OF MONOMER CHIRALITY
}

Roberto Dias Lins

Pacific Northwest National Laboratory, Richland, Washington 99352-0999, USA

Ricardo Ferreira*

Departamento de Química Fundamental, Universidade Federal de Pernambuco, Cidade Universitária,

50670-901 Recife - PE, Brazil

Recebido em 26/9/05; aceito em 20/1/06; publicado na web em 6/6/06

Poly- $L$-alanine forms stable right-handed $\alpha$-helices, whereas Poly- $D$-alanine is stable as left-handed $\alpha$ helices.

Keywords: chirality; aminoacids; $\alpha$-helices.

\section{INTRODUCTION}

A few years ago Milton, Milton and Kent ${ }^{1}$ described the total synthesis of the enzyme HIV-1 protease starting from $D$-amino acids. They found ${ }^{2}$ that the $\alpha$-helices of the synthetic $D$-protease are left-handed, in contrast with the $\alpha$-helices of the standard ( $L$-amino acids) proteins, which are, of course, right-handed ${ }^{3}$.

At present it is possible to study the stabilities of homochiral and mixed protein structures with the help of computer simulation techniques ${ }^{4,5}$. For example, using molecular mechanics calculations with the AMBER force field it was possible to show that $D L$-alanine in right-handed $\alpha$-helices is $21.3 \pm 3.4 \mathrm{kcal}$ $\mathrm{mol}^{-1}$ less stable than right-handed $\alpha$-helices made from $L$-alanine ${ }^{6}$. In the present paper we describe very accurate calculations which gives strong support to these findings.

\section{EXPERIMENTAL PART}

The two nonamer Poly- $L$-alanine, one in right and the other left-handed helical conformation, and the left-handed nonamer Poly$D$-alanine, were embedded in a $7.0 \times 7.0 \times 7.0 \mathrm{~nm}$ water box. Water molecules found to be within $0.25 \mathrm{~nm}$ from any peptide atom were removed so that each system resulted in a 6516 atoms (46 solutes atoms and 2141 water molecules). The SPC/E water model ${ }^{7}$ was used to describe the solvent. A $1.0 \mathrm{~nm}$ short-range cutoff was used for all non-bonded interactions, and long-range electrostatics interactions were treated by the SPME method ${ }^{8}$.

The systems were equilibrated in a stepwise fashion in order to eliminate ad atomic contacts in a gradual way by performing $10 \mathrm{ps}$ molecular dynamics simulations at 50,100, 150, 200, 250 and $298.15 \mathrm{~K}$ temperatures. 1ns production run followed the equilibration and properties were recorded every $0.5 \mathrm{ps}$ for analysis. Harmonic potentials of mean force of $100 \mathrm{~kJ} \mathrm{~mol}^{-1}$ force constant each were used to ensure the maintainence of the intramolecular hydrogen bonds, and therefore the helical conformation. These potentials were applied at all $(\mathrm{N}-) \mathrm{H}_{(i)}-\mathrm{O}(=\mathrm{C})_{(i+4)}$ distances and all $\mathrm{N}_{(i)}-\mathrm{H}_{(i)}-\mathrm{O}(=\mathrm{C})_{(i+4)}$ angles restraining those values to the intervals of $1.7-2.2 \AA$ and $170-190^{\circ}$, respectively.

All molecular dynamics simulations were carried out using AMBER96 force field ${ }^{9}$ implemented in the NWCHEM4.5 program $^{10}$

*e-mail: rferreira100@yahoo.com in the isothermal-isobaric ensemble using leapfrog algorithm ${ }^{11}$ with a $1 \mathrm{fs}$ time step. The temperature of the system was kept as 298.15 $\mathrm{K}$ by a weak coupling to a heat bath with relaxation times for solute and solvent of 0.1 and $0.4 \mathrm{ps}$, respectively. The pressure was maintained at 1 bar by anisotropic coordinate scaling with a relaxation time of $0.4 \mathrm{ps}$. SHAKE constrains ${ }^{12}$ with a tolerance of $10^{-4} \mathrm{~nm}$ applied to all bonds involving a hydrogen atom.

\section{RESULTS}

Figure 1 shows the peptide potential of the nonamers Polyalanines as a function of the running times. Table 1 gives the average energies of the nonamers.

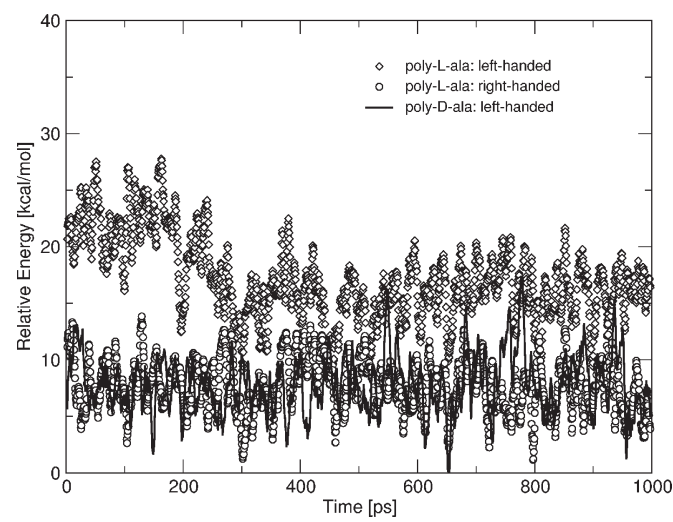

Figure 1. Relative peptide potential energy throughout the 1 ns molecular dynamics simulation runs

Table 1. $\alpha$-helical conformations and corresponding average energies over 1 ns molecular dynamics simulation

\begin{tabular}{lc}
\hline$\alpha$-helical Conformation & $\begin{array}{c}\text { Relative Average Energy } \\
\left(\mathrm{kcal} \mathrm{mol}^{-1}\right)\end{array}$ \\
\hline Right-handed Poly- $L$-alanine & $0.00($ (reference $) \pm 3.86$ \\
Left-handed Poly- $D$-alanine & $0.18 \pm 3.72$ \\
Left-handed Poly- $L$-alanine & $9.45 \pm 4.75$ \\
\hline
\end{tabular}




\section{DISCUSSION}

The question of the chirality of the monomeric species themselves, such as the proteinuous aminoacids, remains unsolved. Frank ${ }^{13}$ has shown that in the precipitation from a racemic solution the difference between the precipitaded enantiomers increases exponentially, whereas the total amount of $\mathrm{L}+\mathrm{D}$ isomers increases more slowly; hence, spontaneous resolution in possible.

On the other hand, it is known that the weak nuclear forces, responsible for the $\beta$ disintegration of nuclei are chiral. Mason and Tranter ${ }^{14}$, using a Hamiltonian with a weak interaction term, have shown that L-alanine is more stable than D-alanine, although only by $10^{-19} \mathrm{eV} /$ molecule.

The answer to the question "why L-amionoacids?" could come from Bioastronomy. If some other biota is ever found, it will be very important to determine the chirality, say, of the extraterrestrial aminoacids. For example, if it is found that they are D-aminoacids, it will greatly strengthen Frank's mechanism ${ }^{13}$. However, if they are $\mathrm{L}$ isomers, the weak force hypothesis will gain more credence.

It seems an inescapable conclusion that the righthandness of protein a-helices (as seen from the amino to the carboxyl terminals) corresponds to a minimization of the energy of helices built from $L$-amino acids. Left handed a-helices would be formed from $D$ amino acids, as shown by Kent et al. ${ }^{1,2}$.

\section{ACKNOWLEDGEMENT}

This work as supported by CNPq and FACEPE.

\section{REFERENCES}

1. Milton, R. C.; Milton, S. C. F.; Kent, S. B. H.; Science, 1992, 256, 445.

2. Kent, S. B. H.; private communication.

3. Pauling, L..; Corey, R. B.; Arch. Biochem. Biophys. 1956, 65, 164.

4. Lins, R. D.; Soares, T. A.; Ferreira, R.; Z. Naturforsch., A: Phys. Sci. 1996, 51,70 .

5. Soares, T. A.; Lins, R. D.; Garret, R.; Ferreira, R.; Z. Naturforsch., A: Phys. Sci. 1997, 52, 89 .

6. Ferreira, R.; J. Mol. Struct. (THEOCHEM) 2002, 580, 1.

7. Berendsen, H. J. C.; Grigera, J. R.; Straatsma, T. P.; J. Phys. Chem. 1987, 91, 6269.

8. Esmann, U.; Perar, L.; Berkowitz, M. L.; Darden, T.; Lee, H.; Pedersen, L. G.; J. Chem. Phys. 1995, 103, 857.

9. Cornell, W. D.; Cieplak, P.; Bayly, C. I.; Gould, I. R.; Merz, K. M.; Ferguson, D. M.; Spellmeyer, D. C.; Fox, T.; Caldwell, J. W.; Kollman, P. A.; J. Am. Chem. Soc. 1995, 117, 5179.

10. Aprà, E.; Windus, T. L.; Straatsma, T. P.; Bylaska, E. J.; de Jong, W.; Hirata, S.; Valiev, M.; Hackler, M.; Pollack, L.; Kowalski, K.; Harrison, R.; Dupuis, M.; Smith, D. M. A.; Nieplocha, J.; Tipparaju V.; Krishnan, M.; Auer, A. A.; Brown, E.; Cisneros, G.; Fann, G.; Fruchtl, H.; Garza, J.; Hirao, K.; Kendall, R.; Nichols, J.; Tsemekhman, K.; Wolinski, K.; Anchell, J.; Bernholdt, D.; Borowski, P.; Clark, T.; Clerc, D.; Dachsel, H.; Deegan, M.; Dyall, K.; Elwood, D.; Glendening, E.; Gutowski, M.; Hess, A.; Jaffe, J.; Johnson, B.; Ju, J.; Kobayashi, R.; Kutteh, R.; Lin, Z.; Littlefield, R.; Long, X.; Meng, B.; Nakajima, T.; Niu, S.; Rosing, M.; Sandrone, G.; Stave, M.; Taylor, H.; Thomas, G.; van Lenthe, J.; Wong, A.; Zhang, Z.; NWChem, A Computational Chemistry Package for Parallel Computers, Version 4.7, Pacific Northwest National Laboratory, Richland, Washington 99352-0999, USA, 2005.

11. Hocknney, R. W.; Methods Comput. Phys. 1970, 9, 136.

12. Ciccotti, G.; Berendsen, H. J. C.; J. Comp. Phys. 1977, 23, 327.

13. Frank, F. C.; Biochem. Biophys. Acta 1953, 11, 459.

14. Mason, S. F.; Tranter, G. E.; Mol. Phys. 1984, 53, 1091. 